\title{
Effect Of Quality Of Work Life On Work Stress, Mental Health, Organizational Citizenship Behavior, And Performance Of Inpatient Nurses In Muhammadiyah Hospitaltype D East Java
}

\author{
Sunaryadi $^{1 *}$, Budiyanto $^{2}$, Suhermin $^{3}$ \\ ${ }^{1,2,3}$ Sekolah Tinggi Ilmu Ekonomi Indonesia (STIESIA) Surabaya, Indonesia \\ * Corresponding author: \\ Email: teguh10setiawan@gmail.com
}

\begin{abstract}
Research related to the relationship between QWL, work stress, mental health, $O C B$ and nurse performance in the type D Muhammadiyah Hospital network in East Java. Based on the problems, phenomena that occur in hospitals today as well as literature studies, researchers examine and analyze the effect of the QWL variable on the performance of inpatient nurses in the type $D$ Muhammadiyah Hospital network in East Java. The population of this study were all nurses with the status of nurses in Muhammadiyah hospital type D, East Java. The sampling technique was saturated sample. The sample of this study was the entire population of nurses with the status of nurses who served in the inpatient room. This study was analyzed using the Partial Least Square method. The results of this study are QWL has a significant and positive effect on the performance of inpatient nurses in the Muhammadiyah type D hospital network in East Java; QWL has a significant and negative effect on the work stress of inpatient nurses in the Muhammadiyah type D hospital network in East Java; QWL has a significant and positive effect on the mental health of inpatient nurses in the Muhammadiyah type D hospital network in East Java; Job stress has a significant and negative effect on OCB of inpatient nurses in the Muhammadiyah type D hospital network, East Java; Mental Health has a significant and positive effect on $O C B$ of inpatient nurses in Muhammadiyah type D Hospital, East Java; QWL has a significant and positive effect on OCB of inpatient nurses in the Muhammadiyah type D hospital network in East Java; $O C B$ has a significant and positive effect on the performance of inpatient nurses in the Muhammadiyah type D hospital network in East Java.
\end{abstract}

Keywords: QWL, work stress, mental health, OCB, performance

\section{INTRODUCTION}

Good nurse performance will have an impact on the quality of services in hospitals, have an impact on patient safety and also have an impact on patient and family satisfaction. Conversely, if the performance of nurses in hospitals is not good, it will have a real impact on the quality of hospital services such as poor service quality, low patient safety levels, and will also have an impact on low patient and family satisfaction levels as well. Until now, the performance of nurses still needs to be improved considering that there are still frequent patient complaints related to dissatisfaction with the services received. Complaints related to dissatisfaction with hospital services often occur, including complaints related to nursing services. Complaints that occur related to dissatisfaction with nursing services will give rise to the opinion that hospital services are not good or of poor quality. The factors that cause or affect employee performance are listed in various literatures and research results, including according to Pentury et al., (2010), stating that the factors that affect performance are work ability, work motivation, performance appraisal, compensation, environment work, organizational citizenship behavior, and commitment. Mathis and Jackson (2010: 97), say that the factors that influence performance include the support received, the existence of the work being done, the relationship with the organization, and empowerment. The factors that affect performance according to Pentury and Mathis are summarized in the quality of work life (QWL). Researchers chose the QWL variable as a variable that affects performance because in the hospital environment the indicators that exist in this variable cover all dimensions that employees perceive to be able to meet their work quality needs. 
Previous studies and studies have not found any differences in the results regarding the effect of QWL on performance, but only differ in the dominance of its dimensions. According to Hijjawi (2017) the dominant dimension is the social dimension, while according to Kumar (2012) the dominant dimension is the wage or salary dimension. QWL was popularized by Cascio (1972) where at that time QWL was carried out to improve performance in automotive companies which resulted in a significant increase in employee performance.QWL is an important factor in creating a work climate in an organizational environment, in this case a hospital. QWL applied in hospitals will create quality of life for individuals in the organization and will increase productivity and good performance within the organization. This is in line with the opinion of Parvar et al., (2003) which states that QWL is an effective program in improving working conditions and organizational effectiveness where QWL has a role in evaluating employees in line with the quality of their work and the quality of their work life as well as the quality of their environmental life. external and internal. QWL has made an important contribution to the hospital and has great concern for the needs of its employees and the quality of their work life. QWL that is implemented properly will greatly affect employee performance, being able to motivate employees to produce optimal performance.In this study, researchers conducted research related to the relationship between QWL, work stress, mental health, OCB and nurse performance in the Muhammadiyah type D hospital network in East Java. Based on the problems and phenomena that occur in hospitals today and referring to previous research studies, the researchers examined and analyzed the effect of the QWL variable on the performance of inpatient nurses in the Muhammadiyah Hospital network type D East Java by placing the QWL variable as an exogenous variable while work stress variables, mental health, OCB and performance variables as endogenous variables.

\section{LITERATURE REVIEW \\ Performance}

According to Cormick and Tifftin (2010), performance is the quantity, quality and time used in carrying out tasks. Quantity is the result that can be calculated the extent to which a person can successfully achieve the goals that have been set. Quality includes the extent to which a person makes mistakes, discipline and accuracy in carrying out his duties. Time is the extent to which a person works in accordance with the specified time span.

\section{Quality of Work Life (QWL)}

According to Idris (2006) states that Quality of Work Life (QWL) refers to a pleasant or unpleasant state in a person's work environment. Its main goal is the development of an excellent working environment for employees as well as for production. The main focus of QWL itself is that the work environment and all work in it must be compatible with people and technology.

\section{Organizational Citizenship Behavior (OCB)}

OCB according to Organ (2005) is an individual's free behavior that is explicitly or indirectly recognized by the formal system, and in aggregate functions effectively and efficiently in an organization. Aggregate functioning refers to people in a group, department, or organization. If only one person, OCB does not have a significant impact on an organization, but if in an organization, in the aggregate, its members have good OCB, the impact on the organization will be felt significantly.

\section{Work Stress}

According to Anwar (1993: 93) work stress is a feeling that suppresses or feels depressed experienced by employees in dealing with their work. Job stress is a pressure due to work that will also affect a person's emotions, thought processes and physical condition, where the pressure comes from the work environment in which the individual is located.

\section{Mental health}

According to Daradjat (2013), mental health is the realization of true harmony between the functions of the soul and having the ability to deal with ordinary problems that occur and feel positively about his happiness and abilities. 


\section{METHODS}

The population of this study were all nurses with the status of Nurses in type D Muhammadiyah hospitals who were members of the East Java Muhammadiyah hospital network, totaling 11 hospitals. The sampling technique in this study was a saturated sample. The sample of this study was the entire population of nurses with nurse status on duty in inpatient rooms, so the respondents used in this study were all samples of hospital inpatient nurses. Each hospital was taken by all respondents from inpatient nurses from all Muhammadiyah Hospital tipt D in East Java. The total number of respondents is 100 respondents. This study was analyzed using the Partial Least Square method which was carried out by making a path diagram, converting the path diagram into structural equations and measurement equations, then estimating parameters using Smart PLS software.

The hypothesis of this research is

1. QWL has a significant and positive effect on the performance of inpatient nurses in the Muhammadiyah type D hospital network in East Java.

2. QWL has a significant and negative effect on the work stress of inpatient nurses in the Muhammadiyah type D hospital network in East Java.

3. QWL has a significant and positive effect on the mental health of inpatient nurses in the Muhammadiyah type D hospital network in East Java.

4. Work stress has a significant and negative effect on OCB of inpatient nurses in the Muhammadiyah type D hospital network, East Java

5. Mental Health has a significant and positive effect on OCB of inpatient nurses in Muhammadiyah Hospital type D, East Java

6. QWL has a significant and positive effect on OCB of inpatient nurses in the Muhammadiyah type D hospital network in East Java.

7. OCB has a significant and positive effect on the performance of inpatient nurses in the Muhammadiyah type D hospital network in East Java.

The following is a research concept framework

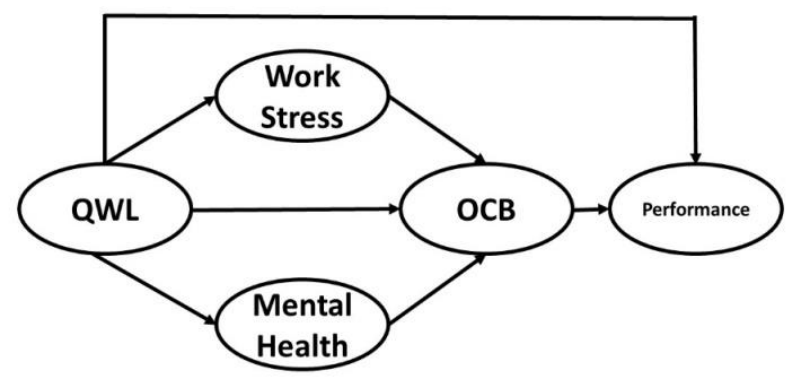

Fig 1. Research Concept Framework

\section{RESEARCH RESULTS AND DISCUSSION}

\section{A. Research Result}

Path coefficients and t-statistic values used to test statistical hypotheses on the structural model were obtained through the bootstrapping process. The processing results for the estimation of the inner model parameters can be seen in Table 1 as follows.

Tabel 1. Result of Output Path Coefficient

\begin{tabular}{llllll}
\hline & Sample (O) & $\begin{array}{l}\text { Average } \\
\text { Sample (M) }\end{array}$ & $\begin{array}{l}\text { Standart } \\
\text { Deviasion } \\
\text { (STDEV) }\end{array}$ & $\begin{array}{l}\text { T Statistik } \\
\text { O/STDEV |) }\end{array}$ & $\begin{array}{l}\text { P } \\
\text { Values }\end{array}$ \\
\hline KM -> OCB & 0,237 & 0,231 & 0,072 & 3,305 & 0,001 \\
\hline OCB -> Kn & 0,392 & 0,374 & 0,115 & 3,417 & 0,001 \\
\hline QWL -> KM & 0,751 & 0,744 & 0,065 & 11,512 & 0,000 \\
\hline QWL -> Kn & 0,461 & 0,475 & 0,119 & 3,893 & 0,000 \\
\hline
\end{tabular}




\begin{tabular}{llllll}
\hline QWL -> OCB & 0,440 & 0,445 & 0,089 & 4,970 & 0,000 \\
\hline QWL -> SK & $-0,379$ & $-0,382$ & 0,165 & 2,300 & 0,022 \\
\hline$S K$-> OCB & $-0,414$ & $-0,413$ & 0,051 & 8,094 & 0,000 \\
\hline PLS B
\end{tabular}

Source: PLS Boostrapping Output

Statistical hypothesis testing was carried out using a significance level of $=5 \%$. Based on the results of the analysis shown in Table 1 above, the interpretation of the results of the inner model hypothesis test is as follows.

- H1. The QWL variable has a significant and positive effect on $\mathrm{Kn}$, the path coefficient with a positive sign is 0.461 and the t-statistic value is 3.893 , the p-value of the results of this test is $0.000<0.05$. So that QWL has a significant and positive effect on $\mathrm{Kn}$.

- H2. The QWL variable has a significant and negative effect on SK. The path coefficient value which is negative is -0.379 and the t-statistic value is 2.300 , the p-value of the test results is $0.022<0.05$. So that QWL has a significant and negative effect on SK.

- H3. The QWL variable has a significant and positive effect on KM. The path coefficient value with a positive sign is 0.751 and the t-statistic value is 11.512 , the p-value from the results of this test is $0.000<0.05$. So that QWL has a significant and positive effect on KM.

- H4. The SK variable has a significant and negative effect on OCB. The path coefficient value which is negative is -0.414 and the t-statistic value is 8.094 , the p-value from the results of this test is $0.000<0.05$. So that $\mathrm{SK}$ has a significant and positive effect on OCB.

- H5. The KM variable has a significant and positive effect on OCB. The path coefficient value which is positive is 0.237 and the t-statistic value is 3.305 , the p-value of the test results is $0.001<0.05$. So that $\mathrm{KM}$ has a significant and positive effect on OCB.

- H6 The QWL variable has a significant and positive effect on OCB. The path coefficient value with a positive sign is 0.440 and the $t$-statistic value is 4.970 , the p-value of the test results is $0.000<0.05$. So that QWL has a significant and positive effect on OCB.

- H7. The OCB variable has a significant and positive effect on $\mathrm{Kn}$. The path coefficient value which is positive is 0.392 and the t-statistic value is 3.417 , the p-value of the test results is $0.001<0.05$. So that OCB has a significant and positive effect on $\mathrm{Kn}$.

\section{B. Discussion}

\section{Quality Work of Life has a significant and positive effect on nurse performance}

The results of the hypothesis test show that Quality Work of Life has a significant effect on the performance of nurses, which means that Quality of work of life has a significant effect on improving the performance of nurses, which also means that the increasing efforts to improve the quality of work of life in hospitals will also increase the performance of nurses. The highest perceived QWL indicator by nurses is the salary indicator. This means that salary is the most important indicator in improving the performance of nurses in addition to other factors in the QWL dimension.

\section{Quality Work of Life has a significant and negative effect on nurses' work stress}

The results of the hypothesis test show that Quality Work of Life has a significant and negative effect on nurses' work stress, meaning that Quality Work of Life has a significant effect on reducing nurses' stress levels in type D hospitals in East Java, which also means that the better efforts to increase QWL, the lower also nurse stress.

\section{Quality Work of Life has a significant and positive effect on the mental health of nurses}

The results of the hypothesis test show that Quality Work of Life has a significant effect on the mental health of nurses. This means that Quality Work of Life has a significant impact on improving the mental health of nurses at Muhammadiyah Hospital type D, East Java, which also means that the better the organization's efforts to improve the Quality of Work of Life, the better the mental health of the nurses. 


\section{Job stress has a significant and negative effect on OCB}

The results of the hypothesis test show that work stress has a significant and negative effect on OCB. This means that work stress has a significant and negative effect on the performance of nurses in type D hospitals, East Java, which means that the lower the stress level of the nurses, the higher the nurse's performance. The results of this study indicate that the average score of all indicators in the stress variable in the low category is close to number one, which indicates that the stress level of nurses in the Muhammadiyah type D hospital environment in East Java is low.

\section{Mental Health has a significant and positive effect on OCB}

The results of hypothesis testing indicate that the mental health of nurses has a significant effect on OCB. This means that mental health has a significant influence on improving the OCB behavior of nurses in type D hospitals in East Java. All indicators in mental health were perceived with a value in the high category by nurses. This means that nurses at type D hospitals in East Java have good mental health. Good mental health is characterized by feeling happy, free from envy and envy, being able to adjust to wherever one is, including at work.

\section{QWL has a significant and positive effect on nurses' OCB}

The results of the hypothesis test show that Quality Work of Life has a significant effect on OCB, meaning that the quality of work of life has a significant effect on OCB of nurses in type D Muhammadiyah Hospital, East Java. The better the efforts to increase QWL, the better the OCB behavior of nurses in East Java type D hospitals. All QWL indicators are perceived as high by nurses, this shows that the hospital has provided a quality of work life as desired by nurses. All dimensions in QWL provide a guarantee of a good quality of work life for nurses so that it will provide a sense of security, comfort, no discrimination, thus fostering good OCB behavior as well.

\section{OCB has a positive effect on performance}

The results of hypothesis testing indicate that OCB has a significant effect on performance. This means that OCB has a significant effect on the performance of nurses in Muhammadiyah Hospital type D, East Java. The path coefficient value which is positive is 0.392 , so the increase in OCB can improve the performance of the nurses. Vice versa, if OCB decreases, it will be followed by a decrease in the performance of the nurses. The highest value of respondents' responses to the OCB variable is the civie virtue indicator. Civie virtue is a sense of pride from nurses for the hospital where they work and a sense of belonging which is an attitude or behavior inherent in nurses in carrying out their duties. This sense of pride and ownership will spur nurses to carry out their duties with feelings of pleasure and pride, thus providing a good performance according to hospital expectations or even exceeding expectations.

\section{CONCLUSION}

Based on the results of the analysis and discussion of the research, several conclusions were obtained as follows:

1. QWL has a significant and positive effect on the performance of inpatient nurses in the Muhammadiyah type D hospital network in East Java.

2. QWL has a significant and negative effect on the work stress of inpatient nurses in the Muhammadiyah type D hospital network in East Java.

3. QWL has a significant and positive effect on the mental health of inpatient nurses in the Muhammadiyah type D hospital network in East Java.

4. Work stress has a significant and negative effect on OCB of inpatient nurses in the Muhammadiyah type D hospital network in East Java.

5. Mental Health has a significant and positive effect on OCB of inpatient nurses in Muhammadiyah Hospital type D, East Java.

6. QWL has a significant and positive effect on OCB of inpatient nurses in the Muhammadiyah type D hospital network in East Java.

7. OCB has a significant and positive effect on the performance of inpatient nurses in the Muhammadiyah type D hospital network in East Java. 
The limitation of this study is that this study is only limited to the network of Muhammadiyah type D hospitals in East Java which is very limited in number. This research was conducted during the COVID-19 pandemic and only used a questionnaire instrument.

\section{REFERENCES}

[1] Abu, T. B. 2012. The Effect of Organizational Justice on Organizational Citizenship Behavior in Government Ministries Centers in Jordan, Islamic University. Economic and Administrative Studies Journal. 20(9): 145-186.

[2] Ackfeldt, A.L. dan V.L. Coote. 2005. A Study of Organizational Citizenship Behaviors in a Retail Setting. Journal of Business Research, 58(6): 151- 159.

[3] Adnan, A. dan Saud. 2015. The effect of Role Overload and Employee Anziety and Qrganizational Citizenship Behaviour. Journal Management Sciences 10 (1): 45 - 54

[4] Anoraga, P. 2014. Psikology kerja. Edisi pertama. PT Rineka Cipta Jakarta

[5] Anwar. 2007. Pengantar Administrasi kesehatan. Bina Rupa Aksara. Jakarta

[6] _ 2014. Sikap Manusia, Teori dan Pengukurannya. Pustaka Pelajar, Jakarta

[7] Arifin, N. 1999. Aplikasi konsep Quality of Work of life dalam upaya menumbuhkan motivasi. Jurnal ekonomi. 2(1) :13-14

[8] 2012. Analisis Kualitas Kehidupan Kerja dan Kepuasan Kerja pada CV. Duta Senenan Jepara. Jurnal Ekonomis. 8 (1): 11-12.

[9] Basher, U. 2010. Impact of Stress on Employees Job performance A Study on banking Sector in Pakistan. International journal of Marketing Studies. 2(1):112-118

[10] Basher, M.R. dan M. H. Daysi. 2014. Relationship Between Quality of work Life and Employee performance: Antecedent and Outcome of Job Satisfaction. World Applied Journal and science. 3 (1): 456-467.

[11] Beehr. T. A. 1987. Psicological Stress in The Workplace. Rouledge. New York.

[12] Behzad dan H. Bezani. 2013. Relationship between Quality Work of Life and performance on Departement chairperson on Estahan University. Procedia-Social and Behavioral Sciences 30 (2011): 1555-1560

[13] Bernardin, H. J. dan Russel, J. E. A. 2003. Human Resource Management (An Experimental Approach). $1^{\text {st }}$ International Edition. Mc Graw Hill Inc. Singapore.

[14] Blau, P. M. 1964. Exchange and Power in Social Life. $1^{\text {st }}$ Edition. Wiley. New York.

[15] Borman, W. C. dan S.J. Motowidlo 2009. Empanding The Criterion Domain to Include Elements \& Extra Role Performance, Josseg Bascs San Fransisco 2 (2): 205-211).

[16] Brook, B. dan Clark, P. (2010). Quality of Nursing Work Life. Nursing Science Quartely. 23(4).

[17] Byars, L. L. dan L. Rue. 2006. Human Resource Management. $8^{\text {th }}$ Edition. McGraw-Hill. USA.

[18] Camman, C. 2009. Productivity of Management through QWL Programs In Frombun. Strategic Human Resource Management. New York: Wiley

[19] Cascio, W. F. 1992. Managemen Human Recources: Productivity QWL and Profits, $3^{\text {rd }}$ edition. Irwin Mc. Graw Hill, inc. Singapore

[20] Chelagat, L. J., C.K. Protas dan K. Ambrose. 2015. Effect of Organizational Citizenship Behavion on Employee Performance in Banking Sector, Nairobi Country, Kenya, International of Business Humanities and Tecnology. 5(4): 20-24

[21] Chin, W. 1998. The Partial Least Square Approachto Structural Equation Modeling.Lawrence EarlbaumAssociate Publisher, University of Huston.USA

[22] Colade, O. dan Osibanjo. 2014. Organizational citizenship behavior, hospital corporate image and performance. Journal of Competitiveness. 6(1): 36-49.

[23] Cormick, Mc. E. J. dan J. Tiffin 2003, Manajemen Kinerja, Alfabeta, Bandung.

[24] Daniels, D., J. Joireman., J. Falvy dan D. Kamdar, 2006. Organizational Citizenship Behavior as Function of Empathy Consideration of Future Consequences, and Employee Time Horizon: An Initial Exploration Using An In-Basket Simulation of OCBs. Journal of Applied Social Psychology. 36 (9): 2266-2292.

[25] Daradjad, Z. 2006, Kesehatan mental. Edisi I. Gunung Agung. Jakarta.

[26] Davis, K. 2010. Personnel Management and Human Resources. $5^{\text {th }}$ Edition. McGraw Hill Ltd. Tokyo.

[27] Departemen Kesehatan Republik Indonesia. Tahun 2002. Indikator Kinerja Rumah Sakit. Cetakan Ketiga. Direktorat Jenderal Pelayanan Medik. Jakarta. 

Keperawatan dan Keteknisian, Direktorat Jenderal Pelayanan Medik. Jakarta.

[29] Dessler, G. 2015. Human Resource Management. 14 ${ }^{\text {th }}$ Edition. Pearson. New York.

[30] Duffy, J. dan J. Lilly. 2013. Do Individual Needs Moderate the Relationships between Organizational Citizenship Behavior, Organizational Trust and Perceived Organizational Support. Institute of Behavioral and Applied Management.12(5):185-197.

[31] Durham, C.C., D. Knight dan E.A. Locke. 1997. Effects of Leader Role, Team-Set Gool Difficulty, Efficacy And Tactics On Team Effectiveness. Organizational Behavior and Human Decision Processes jurnal. 72(2): 203-31.

[32] Dwivedi, S. dan Luxmi. M. 2015. Organizational citizenship behaviors and demographic variables of employees in Indian business process outsourcing sector. The IUP Journal of Organizational Behavior. 15(1): 40-57.

[33] Fahmi, M. 1977, Kesehatan Jiwa dalam keluarga, sekolah dan masyrakat, Edisi 2. Bulan Bintang. Jakarta.

[34] _ 1978, Penyesuaian diri: pengertiannya dan peranannya dalam kesehatan mental, Edisi 1. Bulan Bintang. Jakarta.

[35] Fathi, Z. 2009. Relatonship Qiality of work Life with employee phisichological Well Being. International Journal of Psichology 8(2): 26-31

[36] Fisher, C.D. 2010. Happiness at work. International Journal of Management Reviews, 12(4): 384-412.

[37] Flippo, E. B. 2002. Personal Manajement, Buku edisi ke 2 Alpongo Erlangga. Jakarta.

[38] Gibson, M. J., J. M. Ivacevich., J. H. Donelly. Jr. dan R. Konopaske. 2015. Organization Behavior, Structure, Processes. $14^{\text {th }}$ Edition. Mc. Grow Hill. USA.

[39] Ghozali, I dan K. Aprilia. 2013. Teknik Penyusunan Skala Likert (Summated Scales): Dalam Penelitian Akuntansi dan Bisnis. Cetakan Kedua. Fatawa Publishing. Semarang.

[40] Greenberg. J. dan R.A. Baron. (2012). The role of emosional intelligent and incrosing quality of work life in social participals. Procedia Social and Behavior Sciennces. (46): 31-35.

[41] Griffin, R. W. dan G. Moorhead. 2014. Organizational Behavior. $11^{\text {th }}$ Edition. South- Western, Cengage Learning. Canada

[42] Hall, D. T. 2010. Human Resources Management. $3^{\text {th }}$ Edition. Scott, Foresman and Company. London.

[43] Handoko, T. 2004. Manajement Personalia dan Sumber Daya Manuasia. Edisi VI. BPEF. Yogyakarta.

[44] Hans, A., S.A. Mubeen., N. Mishra. dan A. Hamood. 2015. Study on Occupational Stress and Quality of Work Life in Private Colleges of Oman (Muscat). Global Business and Management Research: An International Journal. 7(8): 55-65

[45] Hartono. 2010. Analisis Item Instrumen. Janafa publishing. Pakanbaru

[46] 2010. Statistik Untuk Penelitian. Pustaka Pelajar. Yogyakarta

[47] Homans, G. C. (1974) Social Behaviour, Its Elimentary form. Rev. Edition. Harcout Brace Jovabovich. New York.

[48] Idris, K., C.R. Rose., R. Beh dan J. Uli, 2006. An Analysis of Quality of Work Life (QWL) and CareerRelated Variables, American Journal of Applied Sciences 3(12): 2151-2159

[49] Ilyas. 2015. Teori, Penilaian dan Penelitian Kinerja. Edisi Kedua (Revisi). Pusat Kajian Ekonomi Kesehatan FKM-UI. Jakarta.

[50] Jalaludin. 2007. Kesehatan Mental. Edisi I, Uinsuka. Jakarta.

[51] Janseen, O. 2001. Fairness Perception as A Moderator in The Curvlinear Relationship Between Job Demand, And Job Performance And Job Satisfaction, Academy of Management Journal. 4(5): 1039 - 1050.

[52] Joireman, J., D.Daniels, J. Falvy, dan D. Kamdar, 2006. Organizational Citizenship Behavior as Function Of Empathy Consideration of Future Consequences, And Employee Time Horizon: An Initial Exploration Using An In-Basket Simulation of OCBs. Journal of Applied Social Psychology. 36(9): 2266-2292.

[53] Joshua, A. J., Ajani, O. John, dan Otabisi, 2010. An Overview of the Effect of Job Stress on Employees Performance in Nigeria Tertiary Hospital. International Journal of Economics. 60(4): 139-153.

[54] Justice, M. dan Kwesi. A. 2014. Work Stress and Quality Work of Life. The mediating Role of Psicological Capital. Reseach Journal in Organizational Psicology and Educational Studies. 3 (5): 350-358

[55] Kanten, S. dan O. Sadulah. 2012, An Empirical Research on Relationship Quality of Work Life Engagement. Procedia Social and Behavioral Sciences (62): 360-368.

[56] Kepmenkes RI Nomor 340 / Menkes / Per / III / 2010 tentang Klasifikasi Rumah Sakit. Jakarta.

[57] Nomor 625 tahun 2010 tentang sistem remunerasi pegawai BLUD rumah sakit. Jakarta.

[58] Koster, F. and K. Sanders. 2007. Serial solidarity: The effects of experiences and expectationson the 
cooperative behavior of employees. International Journal of Human Resource Management. 18(4): 568585.

[59] Kreitner, R. dan Kinicki. 2013. Organizational Behavior. $1^{\text {st }}$ Edition. McGraw-Hill. Boston.

[60] Kumar, A., K. Jain., I. Cary. dan Copper. 2012. Stress and Organization Citizenship Behaviors in Indian Business Process Outsourcing Organizations, IMB management Review. 24: 155-163.

[61] Kusluvan, S. 2012. The Human Dimension: A Review of Human Resources Management Issues in The Tourism and Hospitally Industry. Cornell Hospitality Quarterly 51(2).

[62] Laiba, D.A., A. Anum., A.N. Muhammad. dan U.K. Kashif, 2015. Impact of stress on employees' job performance in business sector of Pakistan, Public Globa Journals Inc. (USA).24(12):23-27

[63] Lowe, G., G. Schellenburg. dan H.S. Shannon, 2003. Correlates of Employees' Perception of a Healthy Work Environment, American Journal of Health Promotion, 17(6): 390-399.

[64] Mangkunegara, A. A. 2007. Evaluasi Kinerja SDM. Cetakan Kedua. Refika Aditama. Bandung

[65] _ 2012. Manajemen Sumber Daya Manusia Perusahaan. Cetakan Kedua. PT Remaja Rosdakarya Offset. Bandung.

[66] Marshall, G., W. Moncrief., W.G. Lassk. dan C.D.Shepherd. 2012. Linking performance outcomes to salesperson organizational citizenship behavior in an industrial sales setting. Journal of Personal Selling \& Sales Management. 32(4): 491-501.

[67] Mathis, R.L. dan Jackson, R. H. 2010. Human Resources Management. $10^{\text {st }}$ Edition.Thomson, South Western. Ohio.

[68] May, B., R. Lau, dan S.K. Johnson. 1999. A longitudinal study of quality of work life and business performance, South Dakota Business Review, 58(1): 1-7.

[69] Melanie, B. 2011. Stress in the workplace: a general overview of the Causes, the effects, and the solutions. Journal of Canadian mental health Association.5(21): 221-224.

[70] Mink. 2011. Seri Manajemen Sumber Daya Manusia (Kinerja/Performance). Edisi Ketiga. PT Elex Media Komputindo. Jakarta.

[71] Miriam, S., dan A.R. Chaudhary. 2015. Stress and health at the workplace :A Review of the Literature

[72] Nadia. (2020), Pengaruh Quality Work of Life dan Organizatioonal Commitment terhadap Organizational Citizenship Behavior pada Karyawan. Jurnal Psilokogi. 1 (1).

[73] Nasir, R., M. S. Mohammadi, dan F. Halim. 2011. Relationship Between Organizational Citizenship Behavior and Task Performance. The Social Science. 6(4): 307-312.

[74] Nawawi, I. 2012. Perencanaan SDM untuk Organisasi Profit yang Kompetitif. Edisi Ketiga. Gajah Mada University Press. Yogyakarta.

[75] Newstrom, J. W. 2011. Organizational Behavior. $10^{\text {th }}$ Edition. McGraw Hill. New York.

[76] Nurina, D. 2019, Pengaruh QWL terhadap kepuasan kerja dan dampaknya terhadap OCB, study pada bank rakyat Indonesia cabang malang. Jurnal Sciens Universitas brawaijaya. 4(2)

[77] Organ, D. W., Podsakoff., dan Scott, B. M. 2008. Organizational Citizenship Behavior: Its Nature, Antecedents, and Consequences. $5^{\text {th }}$ Edition. Sage Publications. London.

[78] 2008. Introduction to Industrial and Organization Psychology. $7^{\text {th }}$ Edition.Scott, Forestman and Company. London.

[79] Pastegari, M., K. Ali., P. Ghariz dan E. Jalil 2013, evaluation of QWL and It's Asosiation with job performance of the nurses, (2013), Jranian Journal of Nursing and Midwiferry Reseach 15 (4), 224-228.

[80] Pentury, G. M., D. Zain., U. Nimran. dan A. Thoyib. 2010. Pengaruh Variabel Antesenden Kinerja terhadap Kepuasaan Kerja dengan Penilaian dan Kompensasi Sebagai Variabel Moderator (Studi pada Manajer Bank di Jawa Timur). Jurnal Aplikasi Manajemen. 8 (3): 887 - 897.

[81] Podsakoff, P. M. dan S.B. Mackenzie. 1997. Organization Citizenship Behavior and The Quantity and Quality of work group performance, Journal of Applied Phycology. 82: 262-270.

[82] Ragel, S. dan V. R. Ragel 2017. The Effect of Job Rotation, Role Stress and Job Satistacion on Organizational Citizenship Behavior of Bank Employees. Asian journal of economies, Business and Aconting, (4): 1-10.

[83] Ritzer, G. (2017). The Sociological Theory. $8^{\text {th }}$ Edition. SAGE Publication. Inc. USA.

[84] Rivera, A.V. (2019). The effect of Quality Work of Life on Organizational Citizenship Behavior. Indian journal of Public Health Research Development. 10 (8): 1469-1474.

[85] Robbins, S. 2015. Organizational Behavior. $9^{\text {th }}$ Edition. Precentice Hall Internationl Inc. New Jersey.

[86] Sarmawa, Suryani, dan I. G. Riana. 2015. Commitment and Competency as Organizational Citizenship Behaviour Predictor and Its Effect on The Performance. International Journal of Economics, Commerce and Management. 3(1): 1-13. 
[87] Shahbasi, B. 2013. Relationship between the Quality of Work Life and performance of department chairperson of Esfahan University and Esfahan medical University. Australian Journal of business and Managemen Research. 1(11): 23-25.

[88] Shahla, N. S., Z. Kohansal dan E. Habibolah. 2016, the Relationship between Organizational Citizenship Behavior, Job Satisfaction and Occupational Stress among Midwives Working in Health Care Conters of Mashad, Iran, Journal of Midwifery and reproductive Health. 4 (2); 622-630.

[89] Shahnawaz, M. 2018. Impact of Occupational Stress, Interpersonal Trust and Organizational Commitment on Valence, OCB and Job Satisfaction. Journal of Management Sciences. 5(1): 38-61

[90] Sikuku, C.A., B. Walmalwa dan D. Katiba, 2017. The Influence of Organizational Stress on Performance Among Empoyees: A case of the Kenya Foresty Reseach Institute. International Journal of Education and Reseach. 5(15):34-38

[91] Sinha, P. dan O.B. Sayeed. 1980. Measuring Quality of Working Life: Development of an Inventory. Indian Journal of Social Work. 41(2): 219

[92] Soo, H.S. dan H. Ali. 2016.The Linkage between Stress and Organizational Citizenship Behavior. Journal of International Bussiness Management 10 (14): 2713-2718

[93] Sirgy, M. J., D. Efraty., P. Siegel dan D. J. Lee, 2001. A New Measure of Quality of Work Life (QWL) Based on Need Satisfaction and Spillover Theories. Social Indicators Research, 55(3): 241-302.

[94] Soegito, E. S. dan U.Narimawati. 2017. The Contribution of Sstress Managemen and Employee Performance toward to Success Company. The Open Psycology Journal. 10: 154-160

[95] Soelaiman. 2017. Manajemen Kinerja; Langkah Efektif untuk Membangun, Mengendalikan dan Evaluasi Kerja. Edisi Kelima. PT. Intermedia Personalia Utama. Jakarta.

[96] Sugiyono. 2014. Metode Penelitian Bisnis. Cetakan Kedelapan Belas. Alfabeta. Bandung

[97] Sulistyorini. 2009. Analisis Kinerja Portofolio Saham dengan Menggunakan Metode Sharpe,Treynor dan Jensen. Jurnal Program Study Magister Manajemen Universitas Diponegoro.Semarang

[98] Tang, J. L. 2008. Study of Work Stress, Organizational Comitmen, Job Satisfaction, and Organizational Citizenship Behavior, a Case to Employe What are Taking Futher Education University. The Journal of Human Resources and Adult Learning. 11 (1)

[99] Tarupolo, B. 2002. Warta Kesehatan Kerja. Edisi ke 2. Media Komunikasi Kesehatan Kerja. Jakarta

[100] Tehran, G. M., M. S. Abtahi dan S. Esmaeili. 2013. The Relationship Between Organizational Citizenship Behavior and Performance of the Staff of Qazvin University of Medical Science and Health Services. International Journal of Academic Research in Business and Social Sciences. 3(9): 534-542.

[101] Undang Undang Republik Indonesia Nomor 36 tahun 2009 Tentang Kesehatan. Pasal 1 ayat 6

[102] _ N Nomor 38 tahun 2014 Tentang Tenaga Keperawatan. pasal 53 ayat 1,2,3,4,5,6.

[103] Nomor 44 Tahun 2009 Tentang Rumah Sakit. 28 Oktober 2009. Lembaran Negara Republik Indonesia Tahun 2009 Nomor 153. Jakarta.

[104] Usha, S. dan V. Rohini. 2018. Impact of Quality Work of Life on Work Outcome of Employees in auto moble Companies in Chennai. International Journal of Pure and Applied maintenance. 118(20): 787-799.

[105] Walton, R.E. 1975. Qriteria for Quality of work life. 1th Edition. The Free Press, Life, New York.

[106] Whitmore, J. 2010. Seni Mengarahkan Untuk Mendongkrak Kinerja. Edisi Keduabelas. PT Gramedia Pustaka Utama. Jakarta.

[107] Wibowo. 2016. Manajemen Kinerja. Cetakan Kesebelas. Raja Grafindo Persada. Jakarta.

[108] Williams, L. J. dan Anderson, S. E. 1991. Job Satisfaction and Organizational Commitment as Predictors of Organizational Citizenship and In-Role Behaviors. Journal of Management. 17: 601-617.

[109] Wilson, M. G., D.M. DeJoy., R.J. Vandenberg., H.A. Richardson, dan A.L. McGrath. 2004. Work Characteristics and Employee Health and Well-Being: Test of a Model of Healthy Work Organization, Journal of Occupational and Organizational Psychology, 77(4): 565-588.

[110] Wirawan, I. B. 2014. Teori-Teori Sosial dalam Tiga Paradikma. Edisi Pertama. Cetakan Keempat. Prenada Media Group. Jakarta.

[111] Yahaya, A., N. Yahaya., H. Maalip., J. Ramli, dan M.K. Malin. 2012, the realtionshipm between Ocuptional stress, organitational commitment and job statisfaction With Organitazional Citizendhip Archieveve Des Sciences. 65(3): 20. 